\title{
The "Substantial Relation" Question in Gender Discrimination Cases
}

The United States Supreme Court has interpreted the equal protection clause of the fourteenth amendment ${ }^{1}$ to require that statutes containing gender-based classifications satisfy an intermediate level of judicial review. ${ }^{2}$ Unlike "strict scrutiny," which almost always results in the invalidation of the challenged statute, ${ }^{3}$

1 U.S. ConsT. amend. XIV, $\S 1$ ("No state shall . . . deny to any person within its jurisdiction the equal protection of the laws."). The same constraints placed upon the states by the equal protection clause of the fourteenth amendment are placed upon the federal government by the due process clause of the fifth amendment. See, e.g., Weinberger v. Wiesenfeld, 420 U.S. 636, 638 n.2 (1975); Schneider v. Rusk, 377 U.S. 163, 168 (1964); Bolling v. Sharpe, 347 U.S. 497,499 (1954).

2 Until the mid-1970's, the Supreme Court followed a "two-tier" approach in its equal protection jurisprudence, analyzing classifications under either the "rational basis" test or the "strict scrutiny" test. Compare Railway Express Agency v. New York, 336 U.S. 106, 10910 (1949) (rational basis), with Loving v. Virginia, 388 U.S. 1, 11 (1967) (strict scrutiny). Gender classifications were originally subjected only to the rational basis test, LAURENCE Tribe, American Constitutional Law \$ 16-24, at 1060 (1978), and consequently were usually upheld, see, e.g., Goesaert v. Cleary, 335 U.S. 464, 466-67 (1948) (upholding statute prohibiting a woman not the wife or daughter of a tavern owner from becoming a bartender), disapproved in Craig v. Boren, 429 U.S. 190, 210 n.23 (1976). In the early 1970's, however, it became clear that while the Court purported to apply a rational basis standard in gender cases, it actually began to employ a more rigorous level of scrutiny. See Reed v. Reed, 404 U.S. 71, $75-77$ (1971) (invalidating state statute preferring males over females in the administration of estates); see also L. TRIBE, supra, § 16-25, at 1063; Gunther, In Search of Evolving Doctrine on a Changing Court: A Model for a Newer Equal Protection, 86 HARv. L. REv. 1, 34 (1972); infra notes 30-39 and accompanying text (discussing Reed). In fact, a plurality of four justices in Frontiero v. Richardson, 411 U.S. 677 (1973) (invalidating federal statute automatically providing benefits to married servicemen, but requiring servicewomen to demonstrate the dependence of their husbands), argued that gender classifications should be considered "suspect" and thus subject to strict scrutiny, $i d$. at 688 . See infra notes 40-52 and accompanying text (discussing Frontiero). In 1976 the Court settled on an "intermediate" level of scrutiny-often called "heightened" scrutiny-for gender discrimination cases. See Craig v. Boren, 429 U.S. 190, 197 (1976) (invalidating statute prohibiting the sale of $3.2 \%$ beer to men, but not women, aged 18-21); infra notes 53-62 and accompanying text (discussing Craig).

3 See, e.g., Loving v. Virginia, 388 U.S. 1, 7-12 (1967) (invalidating statute prohibiting miscegenation); Skinner v. Oklahoma, 316 U.S. 535, 541-42 (1942) (invalidating statute requiring sterilization of certain criminals); see also Gunther, supra note 2, at 8 (strict scrutiny is " 'strict' in theory and fatal in fact"). But see Korematsu v. United States, 323 U.S. 214 (1944) (upholding exclusion of Japanese-Americans from certain areas during World War II); Hirabayashi v. United States, 320 U.S. 81, 100-02 (1943) (upholding curfew for Japanese-Americans). The Court applies strict scrutiny to legislation that classifies on the basis of race, see, e.g., Loving, 388 U.S. at 11 (prohibition of miscegenation), national origin, 
and "rationality review," under which statutes are upheld routinely, ${ }^{4}$ intermediate-level scrutiny involves potentially very difficult line-drawing exercises. To overcome a challenge under the equal protection clause, a gender-based classification "must serve important governmental objectives and must be substantially related to achievement of those objectives." Unfortunately, the requirement that a classification be "substantially related" to an "important" governmental objective is "hardly a precise standard." Indeed, because of the vagueness of the intermediate-level test, its meaning can be understood only by examining the Supreme Court's actual decisions. ${ }^{7}$

The Court has not found especially troublesome the requirement that the legislative objective be "important,"8 but its deci-

see, e.g., Korematsu, 323 U.S. at 216 (restrictions on movement of Japanese-Americans), or that infringes a "fundamental interest," see, e.g., Skinner, 316 U.S. at 541 (sterilization of criminals).

4 See, e.g., United States R.R. Retirement Bd. v. Fritz, 449 U.S. 166 (1980) (upholding federal statute effectively providing, in some situations, more retirement benefits to those who had worked first for a non-railroad employer and then a railroad employer than to those who had worked first for a railroad employer and then a non-railroad employer); New York City Transit Auth. v. Beazer, 440 U.S. 568, 587-94 (1979) (upholding rule excluding methadone-program participants from employment as bus drivers). But see, e.g., United States Dep't of Agriculture v. Moreno, 413 U.S. 528 (1973) ("mere rationality" review used to strike down federal statute denying food stamps to households containing unrelated persons). The Court applies rationality review to all classifications that neither involve a suspect class nor are based on alienage, illegitimacy, or gender. To these last three types of classifications, the Court applies intermediate-level scrutiny. See, e.g., Plyler v. Doe, 457 U.S. 202, 223-24 (1982) (alienage); Trimble v. Gordon, 430 U.S. 762, 766-67 (1977) (illegitimacy); Craig v. Boren, 429 U.S. 190, 197 (1976) (gender).

${ }^{3}$ Craig v. Boren, 429 U.S. 190, 197 (1976).

${ }^{6}$ Meloon v. Helgemoe, 564 F.2d 602, 604 (1st Cir. 1977) (Coffin, C.J.), cert. denied, 436 U.S. 950 (1978).

- Commentators have found the intermediate-level formula vague, and one concluded that "the middle tier has no predictable application. Whether or not a given classification furthers an 'important governmental interest,' or is 'substantially related' to this interest, are subjective determinations, and a conservative majority is as likely to conclude one way as a liberal majority is to conclude the other." Hull, Sex Discrimination and the Equal Protection Clause: An Analysis of Kahn v. Shevin and Orr v. Orr, 30 Srracuse L. Rev. 639, 671 (1979); see also Note, Refining the Methods of Middle-Tier Scrutiny: A New Proposal for Equal Protection, 61 TEx. L. REv. 1501, 1554 (1983) (Craig v. Boren test "is inadequate to support consistent decisionmaking absent precise definitions of its embodying elements"); Note, Equal Protection and the "Middle-Tier": The Impact on Women and Illegitimates, 54 Notre Dame Law. 303, 321 (1978) (noting the "confusion and inconsistency generated" by the Court's middle-tier cases).

s The Court has typically found the legislative objective "important." See, e.g., Caban v. Mohammed, 441 U.S. 380, 391 (1979) (well-being of illegitimate children); Orr v. Orr, 440 U.S. 268, 280 (1979) (provision for needy spouses and compensation for past discrimination); Craig v. Boren, 429 U.S. 190, 199-200 (1976) (enhancement of traffic safety). But see, e.g., Mississippi Univ. for Women v. Hogan, 458 U.S. 718, 727-30 (1982) (state failed to establish "important" purpose in limiting enrollment in nursing school to women); Orr, 440 
sions reveal an interesting problem in determining whether a gender-based classification is "substantially related" to its objective. As the intermediate-level test has evolved, two different views of the "substantial relation" requirement have appeared in the decisions. Both views start with what might be called "conventional" equal protection analysis. 9 This approach requires the state to show a substantial difference between men and women that is relevant to the classification-that is, that the reason for burdening members of one sex does not apply with the same force to members of the other sex. The first view stops here. The second view, however, goes beyond this traditional inquiry and requires that, in addition to pointing out relevant differences between men and women, the government also advance a sufficiently good reason for not treating the sexes identically.

This comment examines the second approach as it has developed in the Supreme Court's opinions. Part I discusses intermediate scrutiny and explains the two possible approaches. Part II examines the Supreme Court decisions that anticipate, enunciate, and refine the intermediate-level tests. While the traditional approach, which looks only at relevant differences, has been most prominent in the Court's opinions, the possibility that the government must also show that there is a good reason for differential treatment has recently been discussed openly by the Court, but the Court has yet to decide unambiguously which test is appropriate. Part III analyzes the evolution of the Court's treatment of the "substantial relation" question and considers the implications of the additional requirement that there be a good reason for genderspecific treatment. This requirement certainly would tighten the traditional "relevant differences" requirement; it might also be founded upon a different concept of equality than that embodied in the traditional approach.

U.S. at 279 (preference for family unit in which wife is dependent not an allowable purpose). The Court has generally stated that administrative efficiency is not a sufficiently important objective to sustain a gender classification, see, e.g., Craig v. Boren, 429 U.S. 190, 198 (1976); infra notes 38, 50 and accompanying text, but it has also indicated that administrative savings might be significant enough to support a gender classification, see Wengler v. Druggists Mut. Ins. Co., 446 U.S. 142, 152 (1980); see also Rostker v. Goldberg, 453 U.S. 57, 81 (1981) (accepting administrative-convenience justification in military context).

- See infra notes 10-22 and accompanying text. 


\section{General Framework: Approaches to Intermediate-Level SCRUTINY}

Legislation inevitably classifies, ${ }^{10}$ and most such classifications are presumed valid in the face of a challenge under the equal protection clause. ${ }^{11}$ Legislators are generally prohibited only from acting arbitrarily, and the classifications they create normally need only meet a standard of "minimum rationality":12 the objective of the statute must be "legitimate,"13 and the classification must be "rationally related" to the achievement of that objective. ${ }^{14}$ The test thus requires a certain "fit" between the classification at issue and the goal that the legislature seeks to achieve through that classification. ${ }^{15}$ That is, there must be some justification for burdening $^{16}$ one group that does not apply with the same force to the other group. ${ }^{17}$ For example, a state might require its police officers

${ }^{10}$ See, e.g., Massachusetts Bd. of Retirement v. Murgia, 427 U.S. 307, 314 (1976) (per curiam) ("the drawing of lines that create distinctions is peculiarly a legislative task and an unavoidable one"); Archibald Cox, The Role of the Supreme Court in American GovernMENT 59 (1976) ("Classification is an inescapable part of government. The Fourteenth Amendment does not require a State to allow an almost blind man to drive an automobile because it grants licenses to those with perfect vision.").

11 See, e.g., Parham v. Hughes, 441 U.S. 347, 351 (1979) ("every duly enacted state and federal law is entitled" to a "presumption of constitutionality") (citing Lockport v. Citizens for Community Action, 430 U.S. 259, 272 (1977)).

${ }^{12}$ See, e.g., Parham v. Hughes, 441 U.S. 347, 351 (1979) ("legislative classifications are valid unless they bear no rational relationship to a permissible state objective") (citations omitted); supra note 4.

${ }^{13}$ See, e.g., Parham v. Hughes, 441 U.S. 347, 352 (1979); New York City Transit Auth. v. Beazer, 440 U.S. $568,592 \&$ n.39 (1979).

14 See, e.g., Parham v. Hughes, 441 U.S. 347, 351 (1979); New York City Transit Auth. v. Beazer, 440 U.S. 568, 592 \& n.39 (1979); Massachusetts Bd. of Retirement v. Murgia, 427 U.S. 307, 314-15 (1976) (per curiam).

${ }^{16}$ See, e.g., McLaughlin v. Florida, 379 U.S. 184, 191 (1964) (courts must determine "whether the classifications drawn in a statute are reasonable in light of its purpose"); Tussman \& tenBroek, The Equal Protection of the Laws, 37 CALIF. L. REv. 341, 346 (1949) ("A reasonable classification is one which includes all persons who are similarly situated with respect to the purpose of the law."); cf. John HaRT Ely, Democracy and Distrust 145-48 (1980) (discussing fit in the context of suspicious classifications).

${ }^{18}$ Of course, a statute might benefit, instead of burden, a particular group. Indeed, every classification might be seen as "benefiting" one group and "burdening" another, depending on how those terms are defined. For ease of discussion, this comment will refer only to statutory burdens.

${ }^{27}$ This approach to the requirement of a certain "relation" between the classification and its objective can be divided into two parts. First, is the state's objective actually furthered by the statute? Second, is there a sufficient difference, related to the state's objective, between the groups that are treated differently by the statute? Consider, for example, a state prohibition on the provision of water to residents of $X$ County that is defended on the ground that drunk driving will be reduced since the residents of $X$ County will be unable to mix alcoholic drinks containing water. This classification would probably fail the first part of the "relation" test, even under "rationality" review, because the residents of $X$ County 
to retire at age fifty on the ground that those over fifty are not usually healthy enough to perform their duties effectively. Since the quality (unacceptable physical fitness) that motivates the legislation is more prevalent in older police officers than in younger ones, the law's classification exhibits a sufficiently good fit to meet the standard of minimum rationality. ${ }^{18}$

In certain circumstances, however, the presumption of validity is abandoned, and a legislative classification is subjected to a more exacting level of scrutiny. ${ }^{19}$ One way to apply a higher level of scrutiny is simply to tighten the requirements of the conventional approach employed in the "rationality" cases. The intermediatelevel formula used in gender cases suggests just such a technique: the government interest must be "important," instead of merely "legitimate," and the classification must be "substantially," rather

can still consume alcoholic drinks not mixed with water, and drunk driving will not be reduced. The classification would fail the second part of the test if it were shown that residents of $X$ County are no more likely than residents of other counties to mix water-based alcoholic drinks and then drive: in that case the justification for the statutory burden would apply with no more force to residents of $X$ County than to residents of other counties.

${ }_{18}$ See Massachusetts Bd. of Retirement v. Murgia, 427 U.S. 307 (1976) (per curiam) (upholding such a statute). Note, however, that because the classifying trait (in this case, being fifty years old) is typically only a proxy for the quality that is in fact important to the legislature's goal (here, poor physical fitness), a classification may be both underinclusive (some of those under fifty are in poor health) and overinclusive (some of those over fifty are in good health). That is, the "fit" between the classification and its objective may be imperfect. For a discussion of under- and over-inclusiveness, see Tussman \& tenBroek, supra note 15. The question under the equal protection clause then becomes how tight a "fit" is required in order for the classification to survive a constitutional challenge. Where the requirement is only that the classification be "rationally" related to the objective, almost any "fit" at all will suffice. See, e.g., United States R.R. Retirement Bd. v. Fritz, 449 U.S. 166, 178 (1980) (classification not "patently arbitrary"); Murgia, 427 U.S. at 316 (criterion not "wholly unrelated" to the statute's objective).

19 For example, courts tend to examine closely any classification where they suspect that it is the product, not of reasoned legislative decisionmaking, but of an illicit motive, such as prejudice. See, e.g., Plyler v. Doe, 457 U.S. 202, 216 n.14 (1982) (some classifications "suspect" because "more likely than others to reflect deep-seated prejudice rather than legislative rationality"); see also Sunstein, Public Values, Private Interests, and the Equal Protection Clause, 1982 Sup. CT. REv. 127, 140 ("It is now a commonplace that the purpose of heightened scrutiny is to filter out illegitimate motives in cases in which such motives are especially likely to be at work.") [hereinafter cited as Sunstein, Public Values]. This concern might be triggered where, for instance, there is a history of hostility toward a particular group, or the trait identifying the group is immutable, or the group is politically powerless. See, e.g., Plyler, 457 U.S. at 216 n.14 (certain groups historically have suffered prejudice, have been relegated to a position of political powerlessness, and have been disadvantaged by virtue of circumstances beyond their control); Sunstein, Naked Preferences and the Constitution, 84 Colum. L. REv. 1689, 1711, 1715 (1984) (political powerlessness the key factor) [hereinafter cited as Sunstein, Naked Preferences]. See generally, J. ELY, supra note 15, at 148-70. 
than merely "rationally," related to the objective. ${ }^{20}$ As before, the "relation" question would be analyzed by asking if there is a reason, related to the purpose of the legislation, to burden one group that does not apply to the other group, but now a more significant difference would be required. ${ }^{21}$ This traditional method of equal protection analysis, when applied in the gender area, will be referred to as the "similarly-situated" test."

The Court's decisions, ${ }^{23}$ however, raise the possibility of an additional requirement: beyond pointing to some difference between men and women that provides a reason for treating men and women differently, the state must demonstrate that there is a good reason for not treating men and women identically. ${ }^{24}$ In other words, the state must show that the gender-specific statute promotes some worthwhile goal that would not be promoted by a gender-neutral statute. This requirement will be referred to as the "gender-neutral" test.

To illustrate the differences between the similarly-situated and gender-neutral requirements, assume that a state's statutory rape law prohibits "sexual intercourse involving any woman under the age of seventeen, unless such intercourse is with the woman's husband."25 Under this statute, an unmarried woman under the age of seventeen cannot have sex with any male, regardless of his age, while a man under the age of seventeen may engage in sex with women over the age of seventeen. Suppose further that a sixteen-year-old woman is prosecuted, along with her twenty-oneyear-old male companion, for violating the statute. She then chal-

${ }^{20}$ See, e.g., Craig v. Boren, 429 U.S. 190, 197 (1976).

21 The key question, of course, is how much tighter the "relation" requirement should be. One knows for sure only that, because "intermediate" review is involved, the fit should be tighter than mere rationality review, but not as tight as strict scrutiny.

${ }_{22}$ The phrase "similarly situated," because of its extensive use in the "rationality" cases, see, e.g., F.S. Royster Guano Co. v. Virginia, 253 U.S. 412, 415 (1920), might be taken as a term of art indicating "mere rationality" review. As used in this comment, however, the "similarly-situated test" denotes a method of analyzing the relation requirement; it does not imply how strictly the method is applied.

${ }^{23}$ See infra notes 30-122 and accompanying text (discussing the Court's decisions).

24 Where a statute burdens only one sex, the other will always have a "mere" interest in not being subject to that burden, and a state could always advance this as its "good" reason for not extending the law to cover both sexes. Consequently, if the gender-neutral test is to have any meaning, it must require that the interest in not being burdened meet some level of significance. For example, the standard might be that the burden avoided be "important," as the first part of the Craig v. Boren test requires. See 429 U.S. 190, 197 (1976); supra text accompanying note 5 .

${ }^{2 s}$ Cf. Michael M. v. Superior Court, 450 U.S. 464, 466 (1981) (upholding statutory rape law under which only the male was criminally liable) (discussed infra notes 85-106 and accompanying text). 
lenges the statute, claiming that its unequal treatment of men and women violates her equal protection rights. The state responds that it has an important interest in preventing teenage pregnancies because they usually result in harm to the woman, to her child, and (because illegitimate children often become wards of the state) to society. ${ }^{26}$ The state also argues that the gender-specific classification employed in the statute bears a "substantial relationship" to this important interest because only women can become pregnant, so the state need only prohibit sex in those cases where a teenage woman is involved-that is, those instances that can result in a teenage pregnancy. ${ }^{27}$

Assuming that preventing teenage pregnancies is an important state interest under intermediate-level scrutiny ${ }^{28}$ the constitutionality of this statute turns on the "substantial relationship" requirement. In this hypothetical, the inquiry under the similarly-situated test is whether there are differences between men and women, related to preventing teenage pregnancies, that justify burdening women under seventeen, regardless of the age of their partner, that do not apply to men under seventeen who are having sex with older women. ${ }^{29}$ In this case, the state has strong reasons for prohibiting all sex involving unmarried females under the age of seventeen since significant harms result when young women become pregnant. But because males cannot become pregnant, no illegitimate teenage pregnancy can result when teenage males and adult women engage in sex. Since prohibiting male teenagers from having sex with adult women would not further the statute's purpose of preventing teenage pregnancies, the reason for the statutory prohibition does not apply at all to that situation. Consequently, because the "fit" between the classification and the objective is very nearly perfect, the state has justified its statute under the similarly-situated test.

Showing that the sexes are not similarly situated with respect to the state's goal of preventing teenage pregnancies, however, does

${ }^{26}$ Cf. Michael M. v. Superior Court, 450 U.S. 464, 470-71 (1981).

27 Cf. id. at $471-73$.

28 See id. at $470-71$.

20 In order to answer this question, it is useful to imagine the legislature making two independent decisions. First, what benefits are there to regulating the sexual habits of women under the age of seventeen? All relevant factors, such as the harm caused by teenage pregnancies and the costs of preventing these pregnancies, should be taken into account when considering this hypothetical decision. A second, but independent, evaluation, based again on all relevant factors, is made based on the benefits from prohibiting men under seventeen from having sex with adult women. The statute passes the similarly-situated test if these two decisions produce sufficiently different results (however that may be defined). 
not necessarily satisfy the gender-neutral test. The gender-neutral test further requires the state to show a good reason for not treating men and women identically despite the fact that only women can become pregnant. The state must show that its gender-specific statute protects or advances an interest that would not have been advanced by a gender-neutral one. Here, the state might claim that protection of young men's interest in sexual freedom provides the good reason for gender-specific treatment. But the interest of young men in not being burdened in this case may not provide a good reason for differential treatment. If this is the case, and if the state in this illustration cannot demonstrate some other reason for not burdening men under seventeen, then the gender-neutral test will invalidate this classification although the statute survived intermediate scrutiny under the similarly-situated test.

As this hypothetical illustrates, the gender-neutral test is not merely an alternative to the similarly-situated test; rather, it is best regarded as a requirement imposed in addition to the similarly-situated test. This conclusion follows from the nature of the gender-neutral test, under which the government is required to provide a "good reason" for not burdening one sex. If the sexes are similarly situated, then by definition the state cannot provide such a reason. Thus, because no statute can meet the gender-neutral requirement without also passing the similarly-situated test, the gender-neutral test encompasses the similarly-situated test. Furthermore, since the gender-neutral test can result in the invalidation of statutes that do pass the similarly-situated test, the gender-neutral requirement properly is regarded as imposed in addition to the similarly-situated test.

\section{The Court's Decisions}

In order to understand the content of the substantial-relation requirement, one must see how the Court has applied the test in actual cases. These cases reveal that both the similarly-situated and the gender-neutral tests have appeared in the opinions, and that the Court has only recently begun to address the distinctions between the two approaches.

\section{A. The Early Decisions}

1. Reed. The first indication that gender classifications would receive a heightened level of scrutiny came in 1971 with Reed $v$. 
Reed ${ }^{30}$ Reed involved two sections of an Idaho statute providing for the appointment of administrators of intestate's estates. The first section divided those entitled to administer such an estate into several classes, ranked the classes in order of preference, and provided that the administrator was to be picked from the highest class possible. ${ }^{31}$ Another section of the statute provided that males were to be preferred to females if both were members of the same class. ${ }^{32}$ The respondents argued, and the Idaho Supreme Court had held, that the preference statute served the purpose of avoiding costly inquiries to determine which individual was more qualified to serve as an administrator, thus reducing the workload of the Idaho probate courts. ${ }^{33}$

The United States Supreme Court, ostensibly applying rationality review, ${ }^{34}$ struck down the classification:

The objective of [the Idaho priority statute] clearly is to establish degrees of entitlement of various classes of persons in accordance with the varying degrees and kinds of relationship to the intestate. Regardless of their sex, persons within any one of the enumerated classes of [the priority statute] are similarly situated with respect to that objective. By providing dissimilar treatment for men and women who are thus similarly situated, the challenged [preference] section violates the Equal Protection Clause. ${ }^{35}$

The Court's conclusion that the classification was not even "rational," because no relevant characteristic was possessed more often by men than by women, seems disingenuous. Since competence is a relevant factor in choosing an administrator, and since a legislature could reasonably have concluded, as was argued before the Court, ${ }^{36}$ that men generally have more business experience and are therefore likely to be more competent in this regard than

so 404 U.S. 71 (1971).

s1 See id. at 72-73.

32 See id.

ss See id. at 76; Reed v. Reed, 93 Idaho 511, 514, 465 P.2d 635, 638-39 (1970); Frontiero v. Richardson, 411 U.S. 677, 683 (1973) (citing Brief for Appellee, Reed v. Reed, 404 U.S. 71 (1971)).

34 To survive equal protection clause scrutiny, the Court stated, "[a] classification 'must be reasonable, not arbitrary, and must rest upon some ground of difference having a fair and substantial relation to the object of the legislation, so that all persons similarly circumstanced shall be treated alike." Reed, 404 U.S. at 76 (citing F.S. Royster Guano Co. v. Virginia, 253 U.S. 412, 415 (1920)).

ss Reed, 404 U.S. at 77 (citation omitted).

s6 See Frontiero v. Richardson, 411 U.S. 677, 683 (citing Brief for Appellee, Reed v. Reed, 404 U.S. 71 (1971)). 
women, this classification should have survived rationality review. ${ }^{37}$ Thus, the Court in Reed purported to employ traditional equal protection analysis-rationality review using the similarlysituated test-but seemed to require a stronger showing than usual under rationality review.

The Court also stated in Reed that although the government's objective of reducing the workload of probate courts "is not without some legitimacy," using the gender classification "merely to accomplish the elimination of hearings on the merits" was impermissible. ${ }^{38}$ This language may show that the Court accepted the government's objective, but decided that the administrative savings was not a sufficiently good reason to treat the sexes differently. Under this interpretation, the Court's language is consistent with the gender-neutral test. ${ }^{39}$

2. Frontiero. Two years after Reed, the Court decided Frontiero $v$. Richardson, ${ }^{40}$ which involved a challenge to two federal statutes that required servicewomen to prove the dependence of their husbands in order to receive an increased allowance for living quarters and medical benefits for the husband; any serviceman, however, could simply claim his wife as a dependent and automatically receive such benefits, regardless of whether the wife was actually dependent on him. ${ }^{41}$ The apparent justification ${ }^{42}$ for this dif-

${ }^{32}$ See Gunther, supra note 2, at 34 ("Even if the requirement be that the means bear a 'significant relationship' to the state's purpose, or contribute substantially to its achievement, the test would seem to have been met in Reed. Only by importing some special suspicion of sex-related means . . can the result be made entirely persuasive.") (footnotes omitted).

ss Reed, 404 U.S. at 76.

39 The suggestion that language in Reed supports the gender-neutral test should be taken with caution. First, since the Court held that the statute did not pass the similarlysituated test, the result in Reed did not depend upon the existence of any additional requirements. Second, the Court gave no express indication that it was thinking in terms of the gender-neutral test, and one should be careful about shoehorning the Court's reasoning into a mode of analysis that it was not purporting to apply. Finally, the opinion might indicate only that the Court found administrative convenience in this case to be a "legitimate," but not an "important," government interest. See Craig v. Boren, 429 U.S. 190, 197-98 (indicating that the state objective in Reed, viz., reducing the workload on courts, failed the "importance" test). If this is the case, then the Court did not even need to reach the question of the relationship between the statute's classification and the government interest under the intermediate-level test announced later in Craig. But see Reed, 404 U.S. at 77 (stating that the classification did not "advance[]" the government's interest in a manner consistent with the equal protection clause) (emphasis added).

40411 U.S. 677 (1973).

41 Id. at 678.

62 The legislative history of the statute did not specify the reasons for the classification, but the Court accepted the District Court's conclusion that the gender distinction was drawn for purposes of administrative convenience. See id. at 681; Frontiero v. Laird, 341 F. 
ferential treatment was that, because wives usually depend upon their spouses while husbands rarely do, and because approximately ninety-nine percent of all members of the military are male, ${ }^{43}$ such differential treatment would lead to a "considerable saving of administrative expense and manpower." "44 The Court nevertheless struck down the statute; a plurality of four Justices applied strict scrutiny on the ground that gender is a suspect class. ${ }^{45}$

The plurality noted that the statute provided differential treatment of men and women in two respects, First, a female whose spouse was dependent on her had to prove that dependence in order to receive benefits, while a male did not; second, the statute denied benefits to a servicewoman who did not support her husband while granting benefits to a serviceman who did not support his wife. ${ }^{46}$ The plurality concluded that the statute thus "command[ed] 'dissimilar treatment for men and women who are . . . similarly situated." "47 This language and analysis, taken directly from Reed, ${ }^{48}$ is a straightforward application of the similarly-situated test.

After finding that men and women were similarly situated for the purposes of the statute, the plurality addressed the government's argument that the classification was administratively efficient. The plurality rejected this argument, noting that the savings were uncertain ${ }^{49}$ and citing Reed for the proposition that it is impermissible to draw the gender line solely to achieve administrative convenience. ${ }^{\text {s0 }}$ The plurality may have meant only that administrative efficiency by itself is not a sufficiently important government objective. ${ }^{51}$ But its analysis, like that of the Court in

Supp. 201, 207 (M.D. Ala. 1972).

is See Frontiero, 411 U.S. at 681.

4 Id. at 682 (quoting Frontiero v. Laird, 341 F. Supp. 201, 207 (M.D. Ala. 1972), rev'd sub nom. Frontiero v. Richardson, 411 U.S. 677 (1973)).

45 Id. at 688 . The plurality opinion was written by Justice Brennan and joined by Justices Douglas, White, and Marshall.

${ }^{16}$ Id.

${ }^{47}$ Id. (quoting Reed, 404 U.S. at 77).

48 See supra note 47 and accompanying text.

40 Frontiero, 411 U.S. at 689-90. If administrative savings is considered to be one of the objectives of the statute, the plurality's response can be considered an application of the similarly-situated test. See supra note 17.

so Frontiero, 411 U.S. at 690 (quoting Reed, 404 U.S. at 77, 76).

s1 Cf. supra note 39 (discussing same possible interpretation of Reed). Indeed, the plurality in Frontiero purported to apply strict scrutiny, and it may be that administrative savings could never meet the stringent standards of that test. See, e.g., Loving v. Virginia, 388 U.S. 1, 11 (1967) (strict scrutiny requires that classification be justified by a "legitimate overriding purpose"); McLaughlin v. Florida, 379 U.S. 184, 192 (1964) (an "overriding statu- 
Reed, could also be interpreted to mean that, even when the government has shown that there is a significant difference between men and women that is related to an important government objective (providing for dependent servicemen and servicewomen), administrative savings does not provide a sufficiently good reason for not treating men and women identically. ${ }^{52}$

Both Reed and the Frontiero plurality opinion show the Court groping for a coherent alternative to the rigid two-tiered approach under traditional equal protection analysis. Reed purported to apply minimum-rationality analysis and the Frontiero plurality purported to apply strict scrutiny, but both opinions in fact rest on notions that later appear under the rubric of intermediate-level scrutiny.

\section{B. The Explicit Adoption of Intermediate-Level Scrutiny}

1. Craig. In 1976, in Craig v. Boren, ${ }^{53}$ the Court adopted the now familiar intermediate-level test for gender classifications. ${ }^{54}$ In Craig, the Court struck down an Oklahoma statute that prohibited the sale of $3.2 \%$ beer to men aged eighteen to twenty-one, but did not prohibit the sale of such beer to women in that age group. ${ }^{55}$ Arguing that the classification enhanced traffic safety, the state introduced various statistical surveys establishing, inter alia, that about $2 \%$ of men aged eighteen to twenty-one, but only $18 \%$ of women in the same age group, were arrested for drunk driving. ${ }^{56}$

The Court agreed with the state's contention that the Oklahoma statute sought to enhance an important governmental

tory purpose" must justify a racial classification). If not, then the most natural interpretation of Frontiero's discussion of administrative convenience is that this government interest was not sufficiently important. But the fact that the plurality examined the classification to see if it actually achieved any administrative savings, see 411 U.S. at 689-90, indicates that the plurality was not applying strict scrutiny in its traditional sense. Furthermore, the plurality nowhere states that the classification must be "necessary," see, e.g., Loving, 388 U.S. at 11, to a "compelling," see, e.g., Plyler v. Doe, 457 U.S. 202, 217 (1982); Graham v. Richardson, 403 U.S. 365, 376 (1971), or "overriding," see, e.g., Loving, 388 U.S. at 11, interest. Consequently, the plurality may not have intended to apply strict scrutiny as it is usually understood, but only a form of "heightened" scrutiny like that later adopted in Craig v. Boren, 429 U.S. 190, 197 (1976).

${ }^{62}$ The same considerations that caution against labeling Reed a "gender-neutral case," see supra note 39 , apply here as well.

ss 429 U.S. 190 (1976).

s4 Id. at 197 ("To withstand constitutional challenge, . . . classifications by gender must serve important governmental objectives and must be substantially related to achievement of those objectives."); see also supra note 2.

os Craig, 429 U.S. at 191-92.

${ }^{56}$ Id. at 200-01. 
interest, the protection of public health and safety. ${ }^{57}$ It concluded, however, that the statute was not substantially related to this valid objective because, while a disparity of $2 \%$ versus $.18 \%$ "is not trivial in a statistical sense, it hardly can form the basis for employment of a gender line as a classifying device. Certainly if maleness is to serve as a proxy for drinking and driving, a correlation of $2 \%$ must be considered an unduly tenuous 'fit." "\$ss

In its analysis, the Court did not make entirely clear whether it saw the relevant comparison as $2 \%$ versus $.18 \%$ or as $98 \%$ versus $99.82 \%$. The Court's treatment of the statistical evidence suggests that it was concerned with the latter comparison, which shows that the overwhelming majority of both men (98\%) and women $(99.82 \%)$ are similar in that they pose no drinking-anddriving threat. If this is the relevant comparison, Craig can be explained by the similarly-situated test alone.

A lawmaker, however, might naturally compare $2 \%$ with $.18 \%$ and conclude that the drinking-and-driving problem is serious enough among males aged eighteen to twenty-one to warrant a ban on the sale of beer to them, but that so few women in that age group drink and drive that they should not be similarly burdened. $^{6 \theta}$ If this comparison is the relevant one, then the Court's result is not clearly explained by the similarly-situated test. A difference measured by a factor of more than ten would probably be substantial enough to pass the intermediate-level test.

Since Oklahoma offered no state interest that was enhanced by excluding women from the statute's coverage, the result in Craig might be explained by the gender-neutral test. The exclusion of women from the prohibition at issue in Craig clearly would not improve traffic safety, which was the objective of the statute. Further, no countervailing constitutional right to buy beer was at issue, since a flat ban on the sale of beer to both groups would unquestionably be constitutional. ${ }^{60}$ Finally, there was not even a claim that the classification system in Craig was justified by administrative convenience. ${ }^{61}$ Thus, there was no sufficiently good

57 Id. at 199-200.

ss Id. at 201-02 (footnote omitted). Indeed, the Court argued that both Reed and Frontiero involved a far higher correlation between sex and the legitimate classifying factor that sex was meant to approximate. Id. at $202 \&$ n.13.

so See supra notes 10-22 and accompanying text.

${ }^{\circ 0}$ See Craig, 429 U.S. at 210 n.24.

62 Moreover, it does not appear that a colorable claim of administrative convenience could have been made here. The state is not required to single out individuals who are likely to drink and drive; on the contrary, if it wants to prohibit the sale of beer, it must simply 
reason for not simply extending the ban to cover' women as well as men. While the Court's opinion does not address the statute in terms of the gender-neutral test, ${ }^{62}$ its result can perhaps best be explained as an application of these principles.

2. Orr. Three years later, in Orr v. Orr ${ }^{63}$ the Court considered the constitutionality of an Alabama law that provided that husbands, but not wives, might be required to pay alimony upon divorce. ${ }^{64}$ The Court noted that two important objectives might be served by the Alabama statute: "to provide help for needy spouses, using sex as a proxy for need";6s and to "compensat[e] women for past discrimination during marriage." would ordinarily analyze the "needy spouse" objective by asking whether sex was a sufficiently accurate proxy for dependence. ${ }^{67}$ Similarly, the "compensation" rationale would ordinarily be analyzed by asking whether women had been "significantly discriminated against in the sphere to which the statute applied . . . leaving the sexes 'not similarly situated with respect to opportunities' in that sphere ...."

In this case, however, the Court held that "even if sex were a reliable proxy for need, and even if the institution of marriage did discriminate against women," the statute would still be unconstitutional because Alabama already held individualized hearings at which the parties' relative financial situations were considered. ${ }^{69}$

apply the prohibition to both males and females. See 429 U.S. at 210 n.24. The extra cost involved in a statute that covered women as well as men would be minimal.

${ }_{62}$ See supra notes 53-61 and accompanying text.

63 440 U.S. 268 (1979).

B4 ALA. CODE $\$ \$ 30-2-51$ to -52 (1975) (amended 1979); id. $\$ 30-2-53$ (1975) (repealed 1979); see Orr, 440 U.S. at 270 \& n.1.

${ }^{85} \mathrm{Orr}, 440$ U.S. at 280.

${ }^{B 8}$ Id. The statute's challengers in the Supreme Court had argued that it served no other purpose than to enforce "the State's preference for an allocation of family responsibilities." Id. at 279. The Court chose to focus on the two more acceptable interpretations of the statute provided in the opinion of the Alabama Court of Civil Appeals. See Orr, 440 U.S. at 280; Orr v. Orr, 351 So. 2d 904, 905 (Ala. Civ. App. 1977).

${ }_{67}$ Orr, 440 U.S. at $280-81$ (citing Craig v. Boren, 429 U.S. 190, 204 (1976); Reed v. Reed, 404 U.S. 71, 76 (1971)). The Court stated that it would "ordinarily" inquire whether the statute's "gender-classification rests " upon some ground of difference having a fair and substantial relationship to the object of the legislation." " "Orr, 440 U.S. at 280-81 (citations omitted).

${ }^{68}$ Id. at 281 (emphasis in original) (citing Schlesinger v. Ballard, 419 U.S. 498, 508 (1975); Kahn v. Shevin, 416 U.S. 351, 353 (1974)). In these earlier cases, the Court had held that statutory distinctions could be drawn on the basis of gender where they were "efforts ... to remedy th[e] situation" resulting from "overt discrimination [against women] or from the socialization process of a male-dominated culture . . . ." Kahn, 416 U.S. at 353.

${ }^{68} \mathrm{Orr}, 440$ U.S. at 281. 
Since individualized hearings could result in a program that would fulfill the state's goals, and because such hearings already took place, not even the rationale of administrative convenience could be advanced to support Alabama's statute. ${ }^{70}$ The Court concluded that "[w]here, as here, the State's compensatory and ameliorative purposes are as well served by a gender-neutral classification as one that gender classifies and therefore carries with it the baggage of sexual stereotypes, the State cannot be permitted to classify on the basis of sex." "r1

The Court's holding was explicitly based on the assumptions that the government objectives were "important" enough and the sexes sufficiently different for the statute to pass conventional, even heightened, equal protection analysis. ${ }^{72}$ Nevertheless, the statute was struck down because it failed to meet another requirement: the state could not show any reason for not making individualized determinations (and thus treating the sexes identically) using the apparatus that was already established to hear such issues. This requirement-that the state show some good reason for not treating men and women identically-is the essence of the genderneutral test. Indeed, $\mathrm{Orr}$ is the clearest example yet of a decision using that test and showing that it imposes a requirement in addition to those of the conventional similarly-situated test.

3. Wengler. The next year, in Wengler v. Druggists Mutual Insurance Co., ${ }^{73}$ the Court struck down a provision of Missouri's workers' compensation laws that denied a widower death benefits unless he either was mentally or physically incapacitated or proved dependence on his wife's earnings; a widow, however, was granted death benefits without having to make a similar showing. ${ }^{74}$ It was argued that the statute was intended to help widows and was constitutional because the hardship suffered by widows from the loss of a spouse is generally greater than that experienced by widowers. ${ }^{75}$ The Court conceded that providing for needy spouses is an important government objective and that the Missouri statute was

70 Id. at 281 \& n.12.

${ }^{71}$ Id. at 283.

${ }^{2}$ That is, an analysis based on the similarly-situated test.

73446 U.S. 142 (1980).

${ }^{74}$ See id. at 143-46.

${ }^{75}$ Id. at 150 . The Missouri Supreme Court, purportedly applying the test laid out in Craig $v$. Boren, had found that the statutory goal of helping widows was an important governmental objective. Wengler v. Druggists Mut. Ins. Co., 583 S.W.2d 162, 168 (Mo. 1979) (en banc); see also Wengler, 446 U.S. at 150 . The Missouri court also concluded that the discriminatory means employed were substantially related to that objective. $583 \mathrm{~S} . \mathrm{W} .2 \mathrm{~d}$ at 168. 
aimed at that goal. ${ }^{76}$ The Court argued, however, that the "discriminatory means employed" serve[]" that end because the needs of widows and widowers would just as effectively be met if the state granted "benefits to all members of both classes or [paid] benefits only to those members of either class who c[ould] demonstrate their need." fication for employing a gender-based distinction was the assertion that it was administratively efficient to presume dependence on the part of widows while making individualized determinations only in the few cases where men might be dependent.79 Although the Court conceded that administrative savings might be significant enough to justify a gender-based classification, ${ }^{80}$ it held that such a showing was not made out by the "bare assertion" of a significant difference in economic standing between widows and widowers. ${ }^{81}$ Instead, the state must advance a "persuasive demonstration as to what the economic consequences . . . might be if . . . men and women . . . were treated equally under the workers' compensation law."82

While pointing out that the state had merely asserted that in general the economic circumstances of widows and widowers differed significantly, the Court gave no indication that proving the assertion would have saved the classification. ${ }^{83}$ Instead, it focused on whether the state had demonstrated sufficient justification for not treating men and women identically. ${ }^{84} \mathrm{~A}$ showing that men and women are not similarly situated would not, without more, meet this standard. Thus, the gender-neutral test appears to explain the Court's decision in Wengler.

78 Wengler, 446 U.S. at 151.

${ }^{77}$ Id. The Court found that the Missouri "statute discriminates against both men and women." Id. at 147 . Denying death benefits to widowers, in circumstances where similarly situated widows would receive them, discriminates against males; denying working women the absolute entitlement to spousal-protection benefits, where similarly situated working males receive such an entitlement, discriminates against females. Id.

${ }^{78} \mathrm{Id}$. at 151.

79 Id.

so Id. at 152.

s1 Id. at 151-52.

82 Id. at 152.

${ }^{83}$ See id. at 151-52. Indeed, given the strong correlation between sex and economic dependence presented in Frontiero, it is difficult to perceive how the addition of such evidence would have saved the statutory provisions at issue in Wengler. In fact, the Court appeared to concede that the state's assertion was probably correct as an empirical matter. See id. at 151.

s4 See id. at 151-52. 


\section{Recent Decisions}

1. Michael $M$. The legitimacy of the gender-neutral approach, not expressly addressed in the Court's prior opinions, became an issue in 1981. In Michael M. v. Superior Court, ${ }^{85}$ the Court upheld a California statutory-rape law that made it unlawful for a man to have sex with a woman under eighteen years of age and that imposed criminal liability upon the male participant only ${ }^{86}$ The state attempted to justify the statute as an attempt to prevent illegitimate teenage pregnancies. ${ }^{87}$ Although the Court accepted this state interest as important ${ }^{88}$ and upheld the statute, no majority could agree upon a rationale. ${ }^{80}$

After stating that "the Court has had some difficulty in agreeing upon the proper approach and analysis in cases involving challenges to gender-based classifications," "90 a plurality of four Justices, in an opinion written by Justice Rehnquist, concluded that gender classifications may not be " "entirely unrelated to any differences between men and women," "91 but that a statute will be upheld "where the gender classification is not invidious, but rather realistically reflects the fact that the sexes are not similarly situated in certain circumstances."92 The plurality concluded that the classification at issue was "sufficiently related"93 to its objective since virtually all the harms of teenage pregnancy fall on young women, ${ }^{94}$ and that a legislature could reasonably have decided to punish only the party who suffers few of the harmful consequences

\footnotetext{
ss 450 U.S. 464 (1981).

se Id. at 466 . There was an exception if the participants were married. Id.

s7 See id. at 470 .

ss Justice Rehnquist stated in his plurality opinion that "[w]e are satisfied that the . . .
} State has a strong interest in preventing [illegitimate] pregnancy." Id.; cf. id. at 479 \& $\mathrm{n} .9$ (Stewart, J., concurring) (harms are especially acute for the mother); id. at 481-82 (Blackmun, J., concurring) (endorsing plurality's statement that "'teenage pregnancies. . . have increased dramatically over the last two decades' and 'have significant social, medical, and economic consequences for both the mother and her child, and the State" ") (quoting id. at 470).

s9 Justice Rehnquist wrote a plurality opinion in which he was joined by three Justices. Justice Stewart joined in Justice Rehnquist's opinion, but also filed a separate concurring opinion in which he expressed views somewhat different from those of the plurality. Justice Blackmun concurred in the judgment only. Justice Brennan was joined in dissent by Justices Marshall and White, and Justice Stevens filed his own dissenting opinion.

90 Michael M., 450 U.S. at 468 . The plurality referred to the Craig $v$. Boren test as one of several formulations of the appropriate test. Id. at 468-69.

${ }^{91}$ Id. at 469 (quoting Parham v. Hughes, 441 U.S. 347, 354 (1979) (plurality opinion)).

92 Michael M., 450 U.S. at 469 (citations omitted).

9s Id. at 473 .

94 Id. 
of the proscribed conduct.95 Furthermore, the risk of pregnancy already deters females; a sanction applied only to males would thus "roughly 'equalize' the deterrents on the sexes." "96

Justice Brennan, in dissent, argued that the plurality did not correctly apply the substantial-relation test. ${ }^{97}$ In his view, the substantial-relation test required California to "prov[e] that a genderneutral statutory rape law would be less effective than [the genderspecific one at issue] in deterring sexual activity leading to teenage pregnancy."98 The plurality expressly rejected this approach, claiming that Justice Brennan had not accurately stated the "rele-

95 Id. at $471-73$.

${ }^{98}$ Id. at 473 . The plurality thus found that there are reasons for applying a burden to males that do not apply to females: males, who do not suffer the direct consequences of their action, are not naturally deterred, while females, who experience the harmful effects of teenage pregnancy, are already deterred. This reasoning is indicative of the similarly-situated test.

The plurality apparently also found it significant that the statute discriminated against men rather than against women. Without explaining the significance of this observation, the plurality stated near the end of its opinion:

In upholding the California statute we also recognize that this is not a case where a statute is being challenged on the grounds that it "invidiously discriminates" against females. To the contrary, the statute places a burden on males which is not shared by females. But we find nothing to suggest that men, because of past discrimination or peculiar disadvantages, are in need of the special solicitude of the courts.

450 U.S. at 475-76. The implication is that a different standard of judicial review is applied where the government discrimination burdens men than is applied where the burden is on women. This part of the plurality's opinion, however, should be read in light of previous and subsequent cases that clearly contradict it. See, e.g., Craig v. Boren, 429 U.S. 190, 197 (1976) (applying intermediate-level scrutiny to statute discriminating against men in the sale of beer) (discussed supra notes 53-62 and accompanying text); Mississippi Univ. for Women v. Hogan, 458 U.S. 718, 723 (1982) (that a statute "discriminates against males rather than against females does not exempt it from scrutiny or reduce the standard of review") (citations and footnote omitted).

${ }^{87}$ Michael M., 450 U.S. at 488-89 \& n.2 (Brennan, J., dissenting).

${ }^{88} \mathrm{Id}$. at $489 \mathrm{n}$.2. Justice Brennan also stated more generally that the state must show "that a gender-neutral statute would be a less effective means of achieving [the statute's] goal." Id. at 490 (citing Wengler v. Druggists Mut. Ins. Co., 446 U.S. 142, 151-52 (1980) (discussed supra notes 73-84 and accompanying text); Orr v. Orr, 440 U.S. 268, 281, 283 (1979) (discussed supra notes 63-72 and accompanying text)). Justice Brennan seemingly would require that the "good reason" necessary to meet the gender-neutral test be an advancement of the statute's objective. He apparently would not accept men's interest in sexual freedom as a justification for the hypothetical statutory rape law discussed earlier. See supra notes 25-29 and accompanying text. But this reasoning could not be carried so far as to prevent any reason unrelated to the goal of the statute from being "good" enough for gender-specific treatment. For example, suppose the government required that all males undergo an extremely painful treatment to prevent the spread of a contagious disease that could affict only men. While gender-neutral treatment would not be a less effective means of achieving the statute's goals, it would be absurd to suggest that the pain associated with the medical treatment did not provide a sufficient reason for exempting women. 
vant inquiry."99 Thus, the crux of the disagreement between Justice Brennan and the plurality was the legitimacy of the genderneutral test.

Although it appeared to reject the gender-neutral inquiry, the plurality did attempt to answer Justice Brennan's argument. ${ }^{100}$ The state had contended that the statute's efficacy would be impaired if it were gender-neutral since young women would no longer report the men with whom they had intercourse. ${ }^{101}$ The plurality accepted this argument, stating that, because "a female is surely less likely to report violations of the statute if she herself would be subject to criminal prosecution," 102 "[i]t can be plausibly argued that a gender-neutral statute would produce fewer prosecutions than the statute at issue here."103 Justice Brennan responded that this "bare assertion" by the state was insufficient. ${ }^{104}$ Furthermore, Justice Brennan claimed, the state's argument was flawed in two ways: first, actual experience disproved the state's assertion, ${ }^{105}$ and second, "common sense" suggested that subjecting both men and women to sanctions would result in twice the deterrent effect of subjecting only men to sanctions. ${ }^{106}$

Thus, even if the plurality were willing to acknowledge the existence of the gender-neutral test, it would have disagreed with the dissent over the application of the test. Taking a deferential attitude reminiscent of rationality review, the plurality appeared simply to accept the state's assertion at face value, content that it was a "plausible" reason for not treating men and women identically. Under this approach, once the government has shown that the statute satisfies the similarly-situated test, it need only show that the classification is rationally related to the "good reason" required by the gender-neutral test. Justice Brennan, on the other hand, would require the state to "prove" that a gender-neutral law would be less effective than the gender-specific one.

2. Rostker. The question of the validity of the gender-neutral test arose again the same year. In Rostker $v$. Goldberg, ${ }^{107}$ the Court, in a five-four decision, upheld male-only draft registration.

\footnotetext{
${ }^{99}$ Michael M., 450 U.S. at 473.

100 Id. at 473-74 \& n.10.

102 Id. at $473-74$ \& $\mathrm{nn} .9-10$.

${ }^{102} \mathrm{Id}$. at 473-74 (footnote omitted).

${ }_{103} \mathrm{Id}$. at 474 n.10.

${ }^{104}$ Id. at 492 (Brennan, J., dissenting).

${ }^{105} \mathrm{Id}$. at 492-93.

${ }^{108} \mathrm{Id}$. at 493-94.

${ }_{107} 453$ U.S. 57 (1981).
} 
Emphasizing that draft registration is a military concern and that Congress receives special deference when it legislates in the military area, ${ }^{108}$ the Court examined the legislative history of the selective-service statute and concluded that the primary purpose of registration is to prepare for conscripting combat troops. ${ }^{109}$ Because women are ineligible, either by statute or regulation, for combat duty, ${ }^{110}$ Congress concluded that women would not be needed in the event of a draft..11 On this record, the Court upheld the statute.

Men and women, because of the combat restrictions on women, are simply not similarly situated for purposes of a draft or registration for a draft. . . . [In this case] "the gender classification is not invidious, but rather realistically reflects the fact that the sexes are not similarly situated" . . . . The Constitution requires that Congress treat similarly situated persons similarly, not that it engage in gestures of superficial equality. ${ }^{112}$

Justice White and Justice Marshall dissented in separate opinions. ${ }^{113}$ Both relied to some extent on evidence that there would be, in the event of a draft, 80,000 noncombat positions available that could be filled by women. ${ }^{114}$ There was no reason, they argued, to exclude women from registration if there would be some room for them in the draft. ${ }^{115}$ The Court dealt with this argument

108 Id. at 64-68.

109 Id. at $72-76$.

$110 \mathrm{Id}$. at $76-77$.

11 Id. at 77.

112 Id. at 78-79 (quoting Michael M. v. Superior Court, 450 U.S. 464, 469 (1981) (plurality opinion)) (emphasis added). Rostker presented a peculiar situation because the genderbased statute was related to another governmental activity in which sex discrimination was unchallenged and apparently constitutional. Cf. Rostker, 453 U.S. at 83 (White, J., dissenting). Because of the different ways in which the Justices perceived this underlying factor, the Court split not only on the appropriateness of the gender-neutral test, but also on whether men and women were indeed similarly situated for purposes of the statutory classification.

${ }^{113}$ Rostker, 453 U.S. at 83-86 (White, J., dissenting); id. at 86-113 (Marshall, J., dissenting). Justice Brennan joined both dissents.

114 See id. at 84 (White, J., dissenting); id. at 100-02 (Marshall, J., dissenting).

116 See id. at 85-86 (White, J., dissenting); id. at 94-95 (Marshall, J., dissenting). If no women at all would be required for military duty during a war, it would make little sense to register them. If, however, women could be conscripted to fill some positions during a war, it would not "further[] the goal of preparing for a draft of combat troops" to exclude women from registration. See id. at 94 (Marshall, J., dissenting). In Justice Marshall's view, the Court's earlier decisions stood for the proposition that gender-based statutes are unconstitutional unless "a gender-neutral statute would be a less effective means of attaining [the statute's] end." Id.; see infra note 122 and accompanying text. 
in three ways. First, it reasoned that Congress could legitimately conclude that it was not worth the trouble of registering all women when so few positions would be available. ${ }^{116}$ Second, it noted that any need for women could easily be met by volunteers. ${ }^{117}$ Finally, it found that Congress had concluded that "staffing noncombat positions with women during a mobilization would be positively detrimental to the important goal of military flexibility."118

The disagreement between the majority and the dissenters can be seen as a disagreement about the validity of the gender-neutral test. The dissenters argued that Congress had demonstrated no good reason for not including women in a registration. ${ }^{119}$ Although the majority attempted to argue that there was a good reason for not including women in a registration, ${ }^{120}$ it relied primarily on the significant difference between men and women attributable to the fact that only men can serve in combat positions. ${ }^{121}$ Justice Marshall described the difference between his approach and the majority's as follows:

[A]lthough the Court purports to apply the Craig $v$. Boren test, the "similarly situated" analysis the Court employs is in fact significantly different from the Craig $v$. Boren approach. ... [T] $]$ he majority concludes that women may be excluded from registration because they will not be needed in the event of a draft.

This analysis, however, focuses on the wrong question. The relevant inquiry under the Craig $v$. Boren test is not whether a gender-neutral classification would substantially advance important governmental interests. Rather, the question is whether the gender-based classification is itself substantially related to the achievement of the asserted governmental interest. Thus, the Government's task in this case is to demonstrate that excluding women from registration substantially furthers the goal of preparing for a draft of combat troops. . . . [T] he Government must show . . . that a genderneutral statute would be a less effective means of attaining this end. ${ }^{122}$

116 Id. at 81 (majority opinion).

117 Id.

$118 \mathrm{Id}$. at $81-82$.

119 Id. at 83-86 (White, J., dissenting); id. at 92-102 (Marshall, J., dissenting).

$120 \mathrm{Id}$. at $72-83$ (majority opinion).

121 Id. at 76.

122 Id. at 94 (Marshall, J., dissenting) (citation and footnote omitted) (emphasis in original). Marshall claimed that his approach was supported by the Court's decisions in 
Michael M. and Rostker are the first cases in which the Court focuses on the gender-neutral inquiry as an independent, though controversial, step in the "substantial relation" analysis. The plurality in Michael $M$. and the majority in Rostker both claimed to rely on the similarly-situated test alone, yet both felt constrained to address questions raised by the gender-neutral test as well. While the Justices have differed over both the validity of the gender-neutral inquiry and its application, neither side has presented a theoretical justification for its position.

\section{The Difficult Problem of Gender Discrimination}

\section{A. The Evolution of the Gender-Neutral Requirement}

Gender discrimination was the first area of equal protection jurisprudence in which the Court adopted an intermediate level of judicial scrutiny. Before taking this step, the Court had always operated at the extremes: it applied either rationality review (and usually upheld the statute), ${ }^{123}$ or strict scrutiny (and usually struck it down). ${ }^{124}$ Once the Court identified the appropriate standard of review, the result was fairly predictable. With the adoption of an intermediate standard of review in the gender cases, the Court needed to fashion a test that could be used to distinguish valid from invalid classifications without being safely anchored at a doctrinal extreme.

The Court's hesitance and uncertainty in moving to the intermediate standard is evident in its opinions. In Reed, the Court ostensibly adhered to minimum rationality, but with "bite."125 In Frontiero, four members of the Court invoked strict scrutiny, but

Wengler (discussed supra notes 73-84 and accompanying text), and Orr (discussed supra notes 63-72 and accompanying text). See id. at 94-95. Justice Marshall continued:

In this case, the Government makes no claim that preparing for a draft of combat troops cannot be accomplished just as effectively by registering both men and women but drafting only men if only men turn out to be needed. Nor can the Government argue that this alternative entails the additional cost and administrative inconvenience of registering women. This Court has repeatedly stated that the administrative convenience of employing a gender classification is not an adequate constitutional justification under the Craig v. Boren test.

Rostker, 453 U.S. at 95 (citations and footnote omitted).

The majority attempted to show how the statute complied with Marshall's test by pointing out that Congress concluded that a gender-neutral statute would be "positively detrimental" to the statute's goal. Rostker, 453 U.S. at 81-82; supra text accompanying note 118.

${ }^{123}$ See supra note 4 and accompanying text.

${ }^{124}$ See supra note 3 and accompanying text.

${ }^{125}$ See supra notes 30-39 and accompanying text (discussing Reed). 
without the ferocity normally associated with that level of review. ${ }^{126}$ In each opinion, the Court's language appears to comport with traditional equal protection analysis. Yet in each case, the Court's analysis of the most common government justification-administrative efficiency-is, in hindsight, ambiguous. While the most natural reading of the Court's position is that administrative efficiency is not a sufficiently important government objective, the Court's language sometimes suggests that, although a statute has a legitimate objective (for example, providing for dependent spouses or promoting competent management of estates), administrative convenience was an insufficiently good reason for not treating the sexes identically. ${ }^{127}$

When the Court abandoned its attempts to employ the old and familiar approaches and expressly adopted intermediate scrutiny in Craig $v$. Boren, ${ }^{128}$ the transition was viewed warily by several members of the Court. ${ }^{29}$ While Craig did clear up some confusion by providing a new verbal formula, the "substantial relation" requirement was not precise enough to provide real certainty. Furthermore, the decision in Craig is itself confusing with respect to the proper comparison to be made between men and women under the similarly-situated inquiry. ${ }^{130}$ The gender-neutral test can be used to explain the decision, but the Court did not expressly employ that analysis. ${ }^{131}$ To the extent that the gender-neutral test was present in the Court's opinions, it was still hidden behind the labels of conventional equal protection analysis.

In $\mathrm{Orr}^{132}$ and Wengler, ${ }^{133}$ the gender-neutral approach came into sharper focus, though it was still not expressly distinguished from the traditional approach. ${ }^{134}$ A comparison of $\mathrm{Orr}$ and Wen-

226 See supra notes $40-52$ and accompanying text (discussing Frontiero).

${ }^{127}$ See supra notes 38-39, 49-52 and accompanying text.

${ }_{128}$ See supra notes 53-62 and accompanying text (discussing Craig).

${ }^{120}$ See Craig v. Boren, 429 U.S. 190, 210 n.* (1976) (Powell, J., concurring) (expressing reservations about embracing a third level of scrutiny, but admitting that "candor compels the recognition that the . . . 'rational basis' standard of review . . . takes on a sharper focus when we address a gender-based classification"); id. at 211-12 (Stevens, J., concurring) (only one standard should apply in equal protection cases); id. at 215 (Stewart, J., concurring) (statute invalid because it amounts to "total irrationality"); id. at 220-21 (Rehnquist, J., dissenting) (the Court's new standard "comes out of thin air").

130 See supra notes 58-59 and accompanying text.

131 See supra notes 60-62 and accompanying text.

${ }^{132}$ See supra notes 63-72 and accompanying text (discussing $\mathrm{Orr}$ ).

133 See supra notes 73-84 and accompanying text (discussing Wengler).

${ }^{134}$ In Wengler, for example, the Court appears to use the gender-neutral test as an evidentiary requirement to supplement the inherently imprecise similarly-situated inquiry. See Wengler v. Druggists Mut. Ins. Co., 446 U.S. 142, 151-52 (1980) ("bare assertion" of 
gler with the earlier, but similar, case of Frontiero shows how the Court's analysis had changed. All three cases involved a statutory burden that was based on the presumption that women typically are dependent on their husbands while husbands rarely are dependent on their wives. ${ }^{136}$ Frontiero's rejection of administrative convenience as a sufficient justification for discrimination appears from the opinion to fall within the conventional requirement that the government interest be sufficiently important. The gender-neutral requirement, to the extent that it can be found in the opinion at all, is undeveloped. ${ }^{136}$ In Orr and Wengler, however, the implicit application of the gender-neutral inquiry becomes much clearer: the government's objective is accepted as legitimate and important, and administrative convenience is rejected as a sufficiently good reason for treating the sexes differently. ${ }^{137}$ At this point, the Court had moved from confusing discussions of various relevant notions to an approach that more clearly incorporated the genderneutral test.

The gender-neutral inquiry was finally discussed openly in Michael $M{ }^{138}$ and Rostker. ${ }^{138}$ The plurality in Michael $M$. and the majority in Rostker appeared reluctant to carry the substantialrelation test further than required by the traditional similarly-situated inquiry. Nevertheless, both opinions attempted to analyze the challenged statutes under the gender-neutral test, and each felt that it had identified good reasons to explain why the statutes should not have been drawn on a gender-neutral basis. ${ }^{140}$ The dissents in these cases framed the issue in terms of the Court's ac-

difference between men and women not enough; state must make "persuasive demonstration" of economic consequences of gender-neutral treatment); supra notes 81-82 and accompanying text.

${ }^{235}$ In both Frontiero and Wengler, a woman automatically qualified for the statutory benefits because of her presumed dependence, while a man had to prove his dependence in order to qualify. See Frontiero, 411 U.S. at 678; Wengler, 446 U.S. at 143-46. In Orr, the presumption that the wife is usually the dependent spouse was used in an attempt to justify giving women the right to receive alimony while denying men this right altogether. See Orr, 440 U.S. at $270,280$.

${ }^{136}$ See supra notes 49.52 and accompanying text.

137 In fact, when Justices Brennan and Marshall later openly defended the gender-neutral inquiry, each cited both Orr and Wengler for support. See Rostker v. Goldberg, 453 U.S. 57, 94 (1981) (Marshall, J., dissenting); Michael M. v. Superior Court, 450 U.S. 464, 490 (1981) (Brennan, J, dissenting).

${ }_{138}$ See supra notes 85-106 and accompanying text (discussing Michael M.).

${ }_{139}$ See supra notes 107-22 and accompanying text (discussing Rostker).

${ }_{140}$ See Rostker, 453 U.S. at 81-82 (decreased military flexibility); supra note 118 and accompanying text; Michael M., 450 U.S. at 473-74 \& n.10 (plurality opinion) (decreased enforcement of the statutory rape law); supra notes 100-03 and accompanying text. 
ceptance or rejection of the gender-neutral approach, but the results seemed to depend not so much on the validity of the test as on its application. ${ }^{141}$

The reluctance of the Rostker Court to apply the gender-neutral test may be explained by the Court's highly deferential attitude toward congressional decisions in the military area. ${ }^{142}$ Nevertheless, the refusal of a majority of the Court to apply the test, at least with the same force with which it had been applied implicitly in Orr and Wengler, indicates that the Court's perception of the test has changed. Michael $M$. and Rostker have brought the issue out into the open, but the Court has yet to decide definitively whether and to what degree the gender-neutral test is legitimate.

\section{B. Implications and Legitimacy of the Gender-Neutral Requirement}

Although the equal protection clause flatly guarantees "equal protection of the laws,"143 it would be ludicrous to interpret the clause as requiring that each person must be treated the same as every other person. Consequently, legislatures are given wide discretion to classify, ${ }^{144}$ and the dominant view of the equal protection clause holds that the clause prohibits only those classifications that result from illegitimate purposes. ${ }^{145}$ An illegitimate purpose might be rooted in hostility toward certain groups, ${ }^{146}$ but it need not be. In the case of gender, for example, the major concern is that legislators will act on the basis of stereotyped notions about the sexes. ${ }^{147}$

141 See Rostker, 453 U.S. at 94 (Marshall, J., dissenting); supra note 122 and accompanying text; Michael M., 450 U.S. at $489 \&$ n.2, 492-94 (Brennan, J., dissenting); supra notes 97-98, 104-06 and accompanying text.

142 See Rostker, 453 U.S. at 64-65 ("The case arises in the context of Congress' authority over national defense and military affairs, and perhaps in no other area has the Court accorded Congress greater deference."); Korematsu v. United States, 323 U.S. 214, 216-20 (1944) (upholding, under strict scrutiny, wartime classification based on national origin).

143 U.S. CoNST. amend. XIV, § 1.

14 See supra notes 10-14 and accompanying text.

14 See, e.g., Washington v. Davis, 426 U.S. 229, 239 (1976) (disparate impact alone is not enough: racially discriminatory purpose must be shown); see also Sunstein, Public Values, supra note 19 , at $130-31$.

148 For example, the clause is violated by classifications based on a bare desire to harm a certain group. See, e.g., United States Dep't of Agriculture v. Moreno, 413 U.S. 528, 534 (1973); Sunstein, Naked Preferences, supra note 19, at 1689-1704, 1710-17, 1727-32.

${ }_{147}$ See, e.g., Mississippi Univ. for Women v. Hogan, 458 U.S. 718, 724-26 \& nn.10-11 (1982) (purpose of "substantial relation" requirement "is to assure that the validity of a classification is determined through reasoned analysis rather than through the mechanical application of traditional, often inaccurate, assumptions about the proper roles of men and 
Since legislators rarely express their illicit purposes openly, their motives must usually be inferred. One way to infer motive is to look at the "fit" between the legislation's purported objective and the classification employed in the statute. The better the fit, the more likely it is that the legislature adopted the classification in furtherance of the legitimate objective rather than for a prohibited purpose. ${ }^{148}$ How "tight" a fit is required depends on how likely it is that improper motives are behind the statute. ${ }^{149}$ Because the similarly-situated test measures the fit between a classification and its asserted end, it provides one means of uncovering illicit motive. ${ }^{150}$

The gender-neutral inquiry can fulfill the same role. If the government cannot point to a sufficiently important goal that is promoted by a gender-specific classification and that would not also be served by a gender-neutral classification, then the actual motive behind the statute may be the achievement of a goal other than, or in addition to, the legitimate one. Otherwise, there would be no need to draw a gender line at all. If the gender distinction does further a legitimate purpose, then there is reason to believe that the classification was based on reasoned legislative judgment, rather than on illegitimate stereotypes. Viewed in this light, the gender-neutral test differs from the similarly-situated test only in that the former is "stricter" than the latter-that is, fewer statutes will pass the gender-neutral test than will pass the similarly-situated test.

When viewed as a screen for improper motive, the most obvious problem with the gender-neutral test arises from the "error costs" that are associated with it. The judiciary generally owes great deference to the legislature's judgment and expertise. ${ }^{181}$ Courts should not question facially valid legislative decisions ex-

women") (footnote omitted); Orr v. Orr, 440 U.S. 268, 283 (1979) (gender classifications "carry the inherent risk of reinforcing stereotypes about the 'proper place' of women and their need for special protection") (citation omitted); Frontiero v. Richardson, 411 U.S. 677, 684-87 (1973) (plurality opinion) (describing history of paternalism which "put women, not on a pedestal, but in a cage"). Such stereotypes are considered especially unfair in light of the virtual immutability of gender. See, e.g., Caban v. Mohammed, 441 U.S. 380, 398 (1979) (Stewart, J., dissenting) ("Sex-based classifications are in many settings invidious because they relegate a person to the place set aside for the group on the basis of an attribute that the person cannot change.") (citations omitted).

148 See J. ELY, supra note 15, at 145-48.

148 See supra notes 11-21 and accompanying text.

${ }^{250}$ See supra notes 15-22 and accompanying text.

${ }^{151}$ See, e.g., Rostker v. Goldberg, 453 U.S. 57, 64 (1981) (deference due a coequal branch of government); supra note 11 and accompanying text (presumption of constitutionality). 
cept when there is reason to suspect that an illicit motive lies behind the decision; furthermore, the degree of scrutiny should vary according to the strength of this suspicion. ${ }^{152}$ For example, strict scrutiny is the most powerful test of motive because it will result in a statute being held invalid if there is even the slightest chance that it is the product of illicit motive; but strict scrutiny would be wholly out of place in cases where there is no reason to suspect the legislature's motive. ${ }^{153}$ That is, "more" scrutiny is not always better; it may merely be more inaccurate. The legitimacy of the gender-neutral test, then, depends on showing that it is not too "powerful" in relation to the suspicion appropriately attaching to gender classifications.

Nevertheless, requiring the government to demonstrate a good reason for not providing gender-neutral treatment may be justified by reasons that outweigh the danger of invalidating some statutes that are not rooted in illicit motives. The essence of the genderneutral inquiry is a presumption that the sexes should be treated identically: if the government wants to deviate from this ideal, it must provide a persuasive reason for doing so. Thus, the test may rest on a conception of sexual equality as an affirmative value in itself. If so, the gender-neutral test may require that differential treatment be held invalid, even where the fit between means and ends allays the suspicion of illegitimate motive, if the value served by disparate treatment does not outweigh the value attached to equality. ${ }^{154}$ If this view of the gender-neutral test were accepted, it would represent a major development in the law because it appears inconsistent with established equal protection doctrine, which requires evidence of an illicit motive, even where racial discrimination is alleged. ${ }^{155}$

182 See, e.g., supra notes 11-21 and accompanying text; cf. McLaughlin v. Florida, 379 U.S. 184, 191-92 (1964) (presumption of validity removed where classification is based on race).

${ }^{163}$ Likewise, something akin to the gender-neutral test could in theory be applied to economic legislation, but only a weak version of the test would be appropriate given the deference that the Court accords a legislature operating in this area. See, e.g., United States v. Carolene Prods. Co., 304 U.S. 144, $152 \&$ n.4 (1938) (validity of the regulation of commercial activities presumed; more exacting scrutiny reserved for, inter alia, discrimination against "discrete and insular minorities"); supra notes 11-12 and accompanying text; cf. Sunstein, Naked Preferences, supra note 19, at 1715-16 (discussing argument for expanding the coverage of heightened review).

${ }^{154}$ For a critique of the position that treats equality as an affirmative value, see Westen, The Empty Idea of Equality, 95 HARv. L. Rev. 537, 568 (1982) (arguing that the "presumption for equality" is inconsistent with the notion that "likes should be treated alike").

${ }^{155}$ See, e.g., Washington v. Davis, 426 U.S. 229, 239 (1976); supra note 145 and accompanying text. The racial-discrimination cases establishing the motive requirement, however, 


\section{CONCLUSION}

In gender discrimination cases decided under the equal protection clause, the Court usually asks whether there is a reason to burden one sex that does not apply to the other, but often also asks whether there is a "good" reason, beyond the relevant differences between the sexes, for not treating the two identically. The Court has yet to indicate clearly whether it deems the latter approach appropriate, although its most recent opinions seem to suggest that it does not accept the additional inquiry as a strong, separate requirement applicable to all cases of gender discrimination. Rejection of the test might be appropriate for two reasons. First, the test may incorporate an incorrect assumption about the likelihood of illicit legislative motive in gender-classification cases. Second, the gender-neutral inquiry may embody a theory of equality that, according to prevailing doctrine, is not reflected in the equal protection clause. In any event, the Court must address the emergence of the gender-neutral test in order to provide coherence and certainty to the area of intermediate-level scrutiny.

William R. Engles

involved facially neutral statutes that had a disparate impact along racial lines. See, e.g., Washington v. Davis, 426 U.S. 229, 235 (1976). The gender-neutral test, on the other hand, would be applied only to statutes that clearly draw a gender distinction. Depending on the appropriate level of scrutiny, it may be reasonable to say that a facial gender distinction that does not itself further some important interest provides sufficient evidence of illicit motive, even where there is a substantial difference between men and women that is related to the object of the statute. If one takes this view, one could argue that the test will strike down statutes only where the legislature's motive is impugned.

The gender-neutral inquiry might also be valid to the extent that women are seen as a group requiring special judicial protection. Professor John Hart Ely has argued that the Constitution provides protection to those groups that cannot effectively seek redress through normal democratic processes. See J. ELY, supra note 15, at 135-79. Although the claim that women are politically powerless would be difficult to substantiate, cf. id. at 16470 (discussing the appropriate level of "suspectness" in gender cases), the Court has decided that women are a semi-suspect class and are entitled to special judicial solicitude. 